\title{
Effects of dietary coconut oil on fatty acid oxidation capacity of the liver, the heart and skeletal muscles in the preruminant calf
}

\author{
Cécile Piot ${ }^{1}$, Jean-François Hocquette ${ }^{1}{ }^{*}$, Jacques H. Veerkamp ${ }^{2}$, Denys Durand ${ }^{1}$ \\ and Dominique Bauchart ${ }^{1}$ \\ ${ }^{1}$ INRA, Unité de Recherches sur les Herbivores, Centre de Recherches de Clermont-Ferrand/Theix, \\ 63122 Saint-Genès-Champanelle, France \\ ${ }^{2}$ Department of Biochemistry, University of Nijmegen, Nijmegen, The Netherlands
}

(Received 22 July 1998 - Revised 28 January 1999 - Accepted 7 May 1999)

\begin{abstract}
The oxidative capacity of the liver, the heart and skeletal muscles for fatty acids were investigated in preruminant calves fed for $19 \mathrm{~d}$ on a milk-replacer containing either coconut oil (CO, rich in 12:0) or tallow (rich in 16:0 and 18:1). Weights of the total body and tissues did not differ significantly between the two groups of animals but plasma glucose and insulin concentrations were lower in the $\mathrm{CO}$ group. Feeding on the $\mathrm{CO}$ diet induced an 18 -fold increase in the hepatic concentration of triacylglycerols. Rates of total and peroxisomal oxidation of $\left[1-{ }^{14} \mathrm{C}\right]$ laurate, $\left[1-{ }^{14} \mathrm{C}\right]$ palmitate and $\left[1-{ }^{14} \mathrm{C}\right]$ oleate were measured in fresh tissue homogenates. Higher rates of total oxidation in liver homogenate and of peroxisomal oxidation in liver, heart and rectus abdominis muscle homogenates were observed with laurate used as substrate. Furthermore, the relative contribution of peroxisomes to total oxidation was 1.9 -fold higher in the liver and in the heart with laurate than with oleate or palmitate. Finally, the peroxisomal oxidation rate of oleate was 1.5-fold higher in the hearts of calves fed on the CO diet. Whatever the tissue, citrate synthase (CS, EC 4.1.3.7) and cytochrome $c$ oxidase (COX, EC 1.9.3.1) activities were similar between the two groups of calves but the COX : CS activity ratio was lower in the liver of the $\mathrm{CO}$ group. In conclusion, laurate is better catabolized by peroxisomes than long-chain fatty acids, especially in the liver. Elongation of lauric acid after partial oxidation might explain the hepatic triacylglycerol accumulation in calves fed on the CO diet.
\end{abstract}

Fatty acids: Dietary fat: Coconut oil: Preruminant calf

In meat-producing animals, muscle growth results from an appropriate partitioning of nutrients between various tissues. Partitioning of energy-yielding substrates is controlled by complex interactions between substrate availability and fate of nutrients within tissues (for review, see Hocquette et al. 1998; Hocquette \& Bauchart, 1999). From birth to weaning, the preruminant calf is considered as a single-stomached animal, receiving a liquid milk diet in which carbohydrates and fats are the major energy sources. Fats added to milksubstitutes for calves are generally from animal sources (beef-tallow or lard) which provide similar amounts of saturated and unsaturated long-chain fatty acids (Jenkins et al. 1985). However, as a consequence of bovine spongiform encephalopathy, alternate sources of fat and protein from vegetal origin incorporated in milk diets should be of particular interest. Such modifications in chemical composition of the diets must, however, not affect the zootechnical performances of calves as well as the nutritive and organoleptic characteristics of the meat. For instance, it was recently shown that a milk diet containing soyabean oil as a sole source of lipids $(230 \mathrm{~g} / \mathrm{kg}$ on a DM basis) given for 3 weeks to 1-month-old calves reduced both the food intake $(-12.8 \%)$ and body weight gain $(-10.6 \%)$ and led to the development of a fatty liver (for review, see Hocquette \& Bauchart, 1999). In contrast, supplementation of the milkdiet with coconut oil (CO), a natural vegetal oil providing high amounts of medium-chain fatty acids (FA), especially of laurate $(12: 0,424 \mathrm{~g}$ total FA/kg), seems to be of particular interest for the growth of calves. Replacing part of the tallow (TA) with CO in the milk-diet for at least 2 weeks increased protein retention in the preruminant calf (Aurousseau et al. 1983). Furthermore, limited retention of ${ }^{14} \mathrm{C}$-atoms was observed after in vivo administration of $\left[{ }^{14} \mathrm{C}\right]$ lauric acid in pig and rat peripheral tissues (Miller et al. 1971; Leyton et al. 1987). These observations suggest a rapid tissue catabolism of lauric acid favouring energy

\footnotetext{
Abbreviations: CO, coconut oil; COX, cytochrome $c$ oxidase; CS, citrate synthase; FA, fatty acid; LT, longissimus thorasis; RA, rectus abdominis; TA, tallow; TG, triacylglycerol.

* Corresponding author: Dr J.-F. Hocquette, fax +3304 7362 46 39, email hocquet@ clermont.inra.fr
} 
production in the muscle and a $\mathrm{N}$-sparing effect. So far, studies on the effects of dietary lauric acid on lipid metabolism have been mainly performed in the whole animal and focused on energy and $\mathrm{N}$ retention, on tissue lipid composition (Demarne et al. 1978; Craig \& Gatlin, 1995; Yaqoob et al. 1995) and on lipogenesis in the liver of rats (Wiley et al. 1973). In contrast, to our knowledge, no data are available on laurate oxidative capacity of calf liver and muscle, and on how dietary $\mathrm{CO}$ affects catabolic processes within these tissues.

Therefore, the aim of the present study was to determine the ability of tissues to use dietary fatty acids in $\mathrm{CO}$ with regard to energy production for muscle growth. For this, we studied the oxidation of lauric, palmitic and oleic acids both at mitochondrial and peroxisomal levels simultaneously in the most metabolically active tissues or organs: the liver, the heart, and two skeletal muscles in two groups of preruminant calves. Groups were fed, at the same energy intake, on a conventional milk replacer containing either TA or CO. Enzyme activities known to influence the flux through the Krebs cycle (citrate synthase, CS; EC 4.1.3.7) and the respiratory chain (cytochrome $c$ oxidase, COX; EC 1.9.3.1) were also measured since they were shown to be correlated with fatty acid oxidation capacity (Piot et al. 1998).

\section{Materials and methods}

\section{Reagents}

$\left[1-{ }^{14} \mathrm{C}\right]$ Lauric acid $(2.07 \mathrm{GBq} / \mathrm{mmol}),\left[1-{ }^{14} \mathrm{C}\right]$ palmitic acid $(2 \cdot 11 \mathrm{GBq} / \mathrm{mmol})$ and $\left[1-{ }^{14} \mathrm{C}\right]$ oleic acid $(2 \cdot 04 \mathrm{GBq} / \mathrm{mmol})$ were obtained from Amersham International (Amersham, Bucks., UK). ATP, NAD ${ }^{+}$, and cytochrome $c$ were supplied by Boehringer-Mannheim (Meylan, France). Antimycin A, acetyl-coenzyme A, fatty acid-free bovine serum albumin, L-carnitine, lauric acid, palmitic acid, oleic acid, rotenone, oxaloacetate, L-malate, and coenzyme A were purchased from Sigma (St Louis, MO, USA). Other reagents were from Merck (Darmstadt, Germany).

\section{Animals and diets}

The experiment was performed using two groups of five 2-week-old preruminant crossbred Holstein-Friesian male calves. Calves were housed on a litter of wood shavings in an air-conditioned room (relative humidity $80 \%$, mean temperature $20^{\circ}$ ). Animals were fed for $19 \mathrm{~d}$ on a conventional milk replacer containing $160 \mathrm{~g} / \mathrm{kg}$ DM which was composed of $656 \mathrm{~g}$ spray-dried skimmed milk powder $/ \mathrm{kg}$ (i.e. $228 \mathrm{~g}$ protein $/ \mathrm{kg}$ ), $224 \mathrm{~g} \mathrm{TA} / \mathrm{kg}$ (tallow group) or $224 \mathrm{~g} \mathrm{CO} / \mathrm{kg}$ (coconut oil group), $50 \mathrm{~g}$ maize $s t a r c h / k g$, and $10 \mathrm{~g}$ vitamin and mineral mixture/kg (Bridel Retiers SA, 35134 Rennes, France) (for details see Table 1). The total lipid and fatty acid contents of the milk powder amounted to 241 and $220 \mathrm{~g} / \mathrm{kg}$ DM respectively. Liquid milk replacer was fed in buckets in two meals per day at 08.00 and 16.00 hours according to the recommendations of Toullec (1978) to allow an average daily weight gain of $1 \mathrm{~kg}$. Body weight was measured weekly. The night before slaughter, animals were fed four times (at 22.00, 01.00, 04.00 and 07.00 hours)
Table 1. Composition of the experimental milk diets ( $\mathrm{g} / \mathrm{kg} \mathrm{DM})$

\begin{tabular}{lcc}
\hline Ingredient* & $\begin{array}{c}\text { Tallow } \\
\text { diet }\end{array}$ & $\begin{array}{c}\text { Coconut oil } \\
\text { diet }\end{array}$ \\
\hline Spray-dried skimmed milk powder & 656 & 656 \\
Whey & 60 & 60 \\
Tallow & 224 & - \\
Coconut oil & - & 224 \\
Maize starch & 50 & 50 \\
Vitamin and mineral mixture† & 10 & 10 \\
Metabolizable energy value (MJ/kg diet) & 19.65 & 20.00
\end{tabular}

\footnotetext{
* All ingredients were purchased from Bridel Retiers SA, 35134 Rennes, France.

† Contained (per kg mixture): $\mathrm{MgSO}_{4} 0.15 \mathrm{~g}, \mathrm{MgO} 0.30 \mathrm{~g}, \mathrm{FeSO}_{4} 8 \mathrm{mg}, \mathrm{CuSO}_{4}$ $10 \mathrm{mg}, \mathrm{ZnSO}_{4} 80 \mathrm{mg}, \mathrm{MnSO}_{4} 48 \mathrm{mg}, \mathrm{CoSO}_{4} 0.6 \mathrm{mg}, \mathrm{CaCl}_{2} 0.18 \mathrm{mg}$, $\mathrm{Na}_{2} \mathrm{SeO}_{3} 0.15 \mathrm{mg}$, retinol $25000 \mathrm{IU}$, cholecalciferol $5000 \mathrm{IU}, \alpha$-tocopherol $50 \mathrm{mg}$, thiamine $5 \mathrm{mg}$, riboflavine $10 \mathrm{mg}$, panthothenic acid $25 \mathrm{mg}$, niacin $40 \mathrm{mg}$, cyanocobalamin $0.08 \mathrm{mg}$, pyridoxine $4 \mathrm{mg}$, menadione $2.5 \mathrm{mg}$, ascorbic acid $100 \mathrm{mg}$, biotine $0.1 \mathrm{mg}$, folic acid $1.2 \mathrm{mg}$, methionine $0.6 \mathrm{~g}$, lysine chloride $0.8 \mathrm{~g}$, choline $0.8 \mathrm{~g}$, virginiamycin $0.05 \mathrm{~g}$ and sorbitol (Celtic Langlois, St. Jacques de la Lande, France) $3 \mathrm{~g}$.
}

to ensure a constant post-absorptive state (Durand \& Bauchart, 1986). At slaughter (08.00 hours), the body weight of calves averaged 68 (SE 2.7) $\mathrm{kg}$.

\section{Blood and tissue samples}

Blood $(20 \mathrm{ml})$ was collected from the jugular vein into $\mathrm{Na}_{2}$ EDTA tubes (final concentration $3 \mathrm{mM}$ ) at the time of slaughter. Plasma was then separated by centrifugation at $3500 \mathrm{~g}$ for $10 \mathrm{~min}$ at $4^{\circ}$ and stored at $-20^{\circ}$ until analyses.

Calf tissues were taken under general anesthesia with isofluorane $(20 \mathrm{ml} / \mathrm{l} ; 0.5 \mathrm{litre} / \mathrm{min})$, before slaughter of the calf at 5 weeks of age. Tissue samples $(50-100 \mathrm{~g})$ from the liver and from the following muscles were taken at the same site for all animals to minimize sampling error (Hocquette et al. 1995): heart, rectus abdominis (RA) and longissimus thoracis (LT) muscles. Samples of liver, heart and skeletal muscles were quickly trimmed of visible fat and connective tissue. Samples were then cut into pieces which were immediately divided into two parts. One part was rapidly excised with scissors and immediately cooled in ice-cold buffer consisting of $0.25 \mathrm{M}$-sucrose, $2 \mathrm{mM}-\mathrm{Na}_{2}$ EDTA and $10 \mathrm{mM}$-Tris- $\mathrm{HCl}(\mathrm{pH} \mathrm{7.4)}$. Whole homogenates (5 g tissue and $95 \mathrm{ml}$ buffer) were prepared by hand homogenization using a glass-glass homogenizer. Two pestles with different diameters were used (intervening space 0.050 and $0.075 \mathrm{~mm}$ ). The second part was frozen in liquid $\mathrm{N}_{2}$ in less than $10 \mathrm{~min}$ post-slaughtering and stored at $-80^{\circ}$ for subsequent analyses.

\section{Assay for fatty acid oxidation}

FA oxidation rates were measured in tissue homogenates by the procedure of Veerkamp \& Van Moerkerk (1986) and as previously described by Piot et al. (1998). Laurate (12:0), palmitate (16:0) and oleate (18:1) were used as substrates since they were abundant either in CO diet $(12: 0,424 \mathrm{~g} / \mathrm{kg}$ total FA), or in TA diet $(18: 1,378 \mathrm{~g} / \mathrm{kg}$ total FA) or in both diets (16:0, 223 and $128 \mathrm{~g} / \mathrm{kg}$ total FA for TA and CO respectively) (Table 2). Briefly, fatty acid oxidation was determined in a total volume of $0.5 \mathrm{ml}$ containing $25 \mu \mathrm{l}$ (liver) or $100 \mu \mathrm{l}$ (heart or skeletal muscles) homogenate in 
Table 2. Fatty acid composition of the experimental milk diets

\begin{tabular}{lcc}
\hline & \multicolumn{1}{c}{ Tallow diet } & Coconut oil diet \\
\cline { 2 - 3 } Fatty acid & \multicolumn{2}{c}{$\mathrm{g} / \mathrm{kg}$ total fatty acids } \\
\hline $8: 0$ & 1 & 6 \\
$10: 0$ & 1 & 4 \\
$12: 0$ & 29 & 424 \\
$14: 0$ & 42 & 179 \\
$16: 0$ & 223 & 128 \\
$16: 1 n-7$ & 24 & 5 \\
$18: 0$ & 192 & 50 \\
$18: 1 n-9$ & 378 & 121 \\
$18: 2 n-6$ & 24 & 30 \\
$18: 3 n-3$ & 4 & 3 \\
$20: 0$ & 3 & 1 \\
$\sum 20: 1$ & 4 & 2 \\
Others & 75 & 11 \\
$\Sigma$ Saturated fatty acids & 538 & 830 \\
$\sum$ Monounsaturated fatty acids & 420 & 130 \\
$\sum$ Polyunsaturated fatty acids & 43 & 40 \\
S:U ratio & $1 \cdot 2$ & 4.9 \\
\hline
\end{tabular}

S, saturated; U, unsaturated.

*Branched-chain fatty acids and minor fatty acids $(<0 \cdot 1 \%)$.

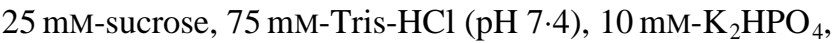
$5 \mathrm{mM}-\mathrm{MgCl}_{2}$ and $1 \mathrm{mM}-\mathrm{Na}_{2}$ EDTA supplemented with $1 \mathrm{mM}^{-N A D^{+}}, \quad 5 \mathrm{mM}-\mathrm{ATP}, \quad 25 \mu \mathrm{M}$-cytochrome $\quad c, \quad 0 \cdot 1$ mM-coenzyme A, $0.5 \mathrm{mM}-\mathrm{L}-$ malate and $0.5 \mathrm{mM}$-L-carnitine. Peroxisomal FA oxidation was determined in the presence of inhibitors of mitochondrial oxidation, i.e. antimycin A and rotenone $(73 \mu \mathrm{M}$ and $10 \mu \mathrm{M}$ final concentrations respectively) as described by Veerkamp \& Van Moerkerk (1986). All assays were performed under conditions which were optimal with respect to time, concentration of palmitate and of tissue material as previously described (Piot et al. 1998) and were made in triplicate. Flasks were preincubated for $5 \mathrm{~min}$ at $37^{\circ}$ before addition of $100 \mu \mathrm{l} 600 \mu \mathrm{M}-\left[1-{ }^{14} \mathrm{C}\right] \mathrm{FA}$ bound to albumin in a 5:1 molar ratio. Specific activity usually averaged $0 \cdot 056-0 \cdot 062 \mathrm{GBq} / \mathrm{mmol}$. Incubation was carried out for $30 \mathrm{~min}$ at $37^{\circ}$ with agitation and stopped by $0.2 \mathrm{ml} 3 \mathrm{M}_{-}-\mathrm{HClO}_{4}$. The released ${ }^{14} \mathrm{CO}_{2}$ was trapped in $0.3 \mathrm{ml}$ ethanolamine-ethylene glycol $(1: 2, \mathrm{v} / \mathrm{v})$ and measured by liquid scintillation counting in $5 \mathrm{ml}$ of Ready Safe (Beckman Instruments Inc., Fullerton, CA, USA). After $90 \mathrm{~min}$ at $4^{\circ}$, the acid incubation mixture was centrifuged for $5 \mathrm{~min}$ at $10000 \mathrm{~g}$ and $150 \mu \mathrm{l}$ supernatant fraction containing ${ }^{14} \mathrm{C}$-labelled $\mathrm{HClO}_{4}$-soluble products was assayed for radioactivity by liquid scintillation. Adequate controls (incubations for $30 \mathrm{~min}$ without homogenate) were applied to correct values of acidsoluble radioactivity for labelled free FA. FA oxidation rates were calculated from the sum of ${ }^{14} \mathrm{CO}_{2}$ and ${ }^{14} \mathrm{C}$-labelled $\mathrm{HClO}_{4}$-soluble products and were expressed as nmol $\mathrm{FA} / \mathrm{min}$ per $g$ tissue wet weight.

\section{Analytical techniques}

Plasma samples. Plasma concentrations of non-esterified FA were determined enzymically using the Wako kit (Unipath SA, Dardilly, France). The triacylglycerol (TG) concentration was measured by the enzymic method using the reagent kit PAP 1000 (Biomérieux, Charbonnières-lesBains, France). Commercial kits were used to determine plasma concentrations of insulin (INSI-PR; Cis Bio International, ORIS group, Gif-Sur-Yvette, France) and of triiodothyronine (T3 Amerlex-M RIA; Ortho-Clinical Diagnostics, Amersham, Bucks., UK). The $\beta$-hydroxybutyrate concentration was measured by an enzymic method according to Barnouin et al. (1986).

Tissue samples. Total lipids of tissue samples (liver, heart, RA and LT) were extracted in chloroform-methanol $(2: 1, \mathrm{v} / \mathrm{v})$ according to the method of Folch et al. (1957). TG were determined from total lipid extracts as described by Leplaix-Charlat et al. (1996).

CS activity was determined in sonicated homogenates by measuring the rate of initial reaction at $412 \mathrm{~nm}$ by means of the 5,5'-dithiobis(2-nitrobenzoate) method as described by Piot et al. (1998). COX activity was assayed in freeze-thawed and sonicated homogenates at $25^{\circ}$ according to Piot et al. (1998) with $90 \mu \mathrm{M}$-cytochrome $c$ as substrate and $50 \mathrm{mM}-\mathrm{K}_{2} \mathrm{PO}_{4}(\mathrm{pH} 7 \cdot 4)$. For CS and COX, 1 unit of enzyme is defined as the amount which, under assay conditions, catalyzes the liberation of $1 \mu \mathrm{mol}$ coenzyme A, or the oxidation of $1 \mu \mathrm{mol}$ cytochrome $c$ respectively, per min at $25^{\circ}$. Activity is expressed as units/g tissue wet weight.

\section{Statistical analyses}

ANOVA of the data was made using the general linear models procedure of SAS, version 6 (Statistical Analysis Systems Inc., Cary, NC, USA). For TG, CS, COX and COX : CS ratio, the tested effects included group of animals (TA, CO), animals tested within the treatment group and tissue. For oxidation rates, the tested effects included group of animals (TA, CO), animal tested within the treatment group and FA. Statistical significance of mean differences between tissues or fatty acids were investigated by ANOVA and by the multiple comparison of Scheffé at $P<0.05$. Comparisons among groups per tissue or per fatty acid were made using the Student's $t$ test for unpaired data. $P<0.05$ and $P<0.10$ were considered statistically significant and as a tendancy for a statistical significance respectively.

\section{Results}

\section{Animal characteristics and plasma variables at slaughter}

Food intake (MJ/d) was similar for the two groups of calves (Table 3). Body weight of the animals as well as average daily weight gain and feed efficiency were similar for the TA and the CO groups (Table 3 ). In addition, the weights of liver, heart, RA and LT did not significantly differ between the two groups of calves (Table 3).

No significant differences between groups were found in plasma non-esterified FA, TG and triiodothyronine levels at slaughter. However, calves fed on a milk-substitute rich in $\mathrm{CO}$ showed lower plasma insulin and glucose levels respectively than the calves from the TA group $(-53 \%, P<0 \cdot 10$ and $-20 \%, P<0.001$ respectively).

TG contents in tissues significantly differed between the two groups of calves (Table 4). TG concentration was 18fold higher in the liver of the $\mathrm{CO}$ group than in that of the TA group $(P<0.001$; Table 4$)$ but no significant differences 
Table 3. Animal characteristics and plasma variables for preruminant calves fed on either a milk-substitute rich in tallow or a milk-substitute rich in coconut oil for 19 days $\ddagger$

(Mean values with their standard errors for five calves per group)

\begin{tabular}{|c|c|c|c|c|}
\hline & \multicolumn{2}{|c|}{ Tallow diet } & \multicolumn{2}{|c|}{ Coconut oil diet } \\
\hline & Mean & SE & Mean & SE \\
\hline Live body weight at $15 \mathrm{~d}$ of age $(\mathrm{kg})$ & $51 \cdot 6$ & 3.46 & $49 \cdot 8$ & $3 \cdot 15$ \\
\hline Average daily weight gain $(\mathrm{g} / \mathrm{d})$ & 855 & 117 & 906 & 103 \\
\hline Live body weight at slaughter (kg) & 68.2 & 5.52 & $66 \cdot 9$ & 1.87 \\
\hline Food intake $(g / d)$ & 1276 & 28.8 & 1282 & $19 \cdot 1$ \\
\hline Metabolizable energy intake (MJ/d) & $25 \cdot 1$ & 0.567 & $25 \cdot 6$ & 0.191 \\
\hline \multicolumn{5}{|c|}{ Organ and tissue weights at slaughter $(\mathrm{kg})$ : } \\
\hline Liver & 1.73 & $0 \cdot 167$ & 1.90 & 0.081 \\
\hline Heart & 0.48 & 0.052 & 0.49 & 0.027 \\
\hline Rectus abdominis & 0.20 & 0.009 & 0.19 & 0.016 \\
\hline Longissimus thoracis & 1.75 & $0 \cdot 137$ & 1.80 & 0.136 \\
\hline \multicolumn{5}{|l|}{ Plasma metabolite concentrations: } \\
\hline Glucose (mmol/l) & $8 \cdot 30$ & 0.118 & $6 \cdot 66^{\star \star *}$ & 0.210 \\
\hline$\beta$-Hydroxybutyrate $(\mathrm{mmol} / \mathrm{l})$ & 0.10 & 0.006 & 0.12 & 0.011 \\
\hline Non-esterified fatty acids (mg/l) & $70 \cdot 7$ & $12 \cdot 20$ & $75 \cdot 8$ & 3.280 \\
\hline Triacylglycerols $(\mathrm{mmol} / \mathrm{l})$ & 0.54 & 0.062 & 0.41 & 0.052 \\
\hline \multicolumn{5}{|l|}{ Plasma hormonal concentrations: } \\
\hline Insulin $(\mu \mathrm{U} / \mathrm{ml})$ & $40 \cdot 9$ & 8.44 & $19 \cdot 2 \dagger$ & 3.27 \\
\hline Triiodothyronine (ng/ml) & $2 \cdot 46$ & $0 \cdot 191$ & 2.33 & 0.147 \\
\hline
\end{tabular}

Mean values were significantly different from that of the tallow diet group: $\nmid P=0.060,{ }^{* * *} P<0.001$.

‡For details of diets see Tables 1 and 2 .

between groups were observed in the heart and skeletal muscles.

\section{Mitochondrial enzyme activities}

As previously described by Piot et al. (1998), the activities of mitochondrial enzymes differed between the bovine

Table 4. Triacylglycerol content of the liver, the heart and skeletal muscles in preruminant calves fed on a milk-substitute rich in tallow (TA) or the same milk-substitute rich in coconut oil (CO) for 19 days $†$ (Mean values with their standard errors for five calves per group)

\begin{tabular}{|c|c|c|c|}
\hline \multirow[b]{2}{*}{ Tissue } & & \multicolumn{2}{|c|}{$\begin{array}{l}\text { Triacylglycerol content (mg/g } \\
\text { tissue wet wt.) }\end{array}$} \\
\hline & & TA diet & CO diet \\
\hline \multirow[t]{2}{*}{ Liver } & Mean & $2 \cdot 22^{a}$ & $40 \cdot 6^{a * \star \star *}$ \\
\hline & SE & 0.109 & $9 \cdot 426$ \\
\hline \multirow[t]{2}{*}{ Heart } & Mean & $4.53^{a}$ & $2 \cdot 62^{b}$ \\
\hline & SE & 1.788 & 0.356 \\
\hline \multirow[t]{2}{*}{ RA } & Mean & $10 \cdot 3^{\mathrm{a}}$ & $15 \cdot 6^{\mathrm{b}}$ \\
\hline & SE & 3.712 & 4.743 \\
\hline \multirow[t]{2}{*}{ LT } & Mean & $3 \cdot 20^{\mathrm{a}}$ & $3.82^{b}$ \\
\hline & SE & 0.500 & 0.774 \\
\hline \multicolumn{4}{|c|}{ Statistical significance of effect of: $P<\ddagger$} \\
\hline \multicolumn{4}{|c|}{ G } \\
\hline \multicolumn{2}{|l|}{ A } & 0.17 & \\
\hline & 0.0001 & \\
\hline \multicolumn{2}{|l|}{$\mathrm{G} \times \mathrm{T}$} & 0.0001 & \\
\hline
\end{tabular}

$\mathrm{RA}$, rectus abdominis; $\mathrm{LT}$, longissimus thoracis.

${ }_{a, b}$ Mean values within a column with unlike superscript letters were significantly different within each group of calves $(P<0.05)$.

Mean values were significantly different between the two groups for a given tissue: ${ }^{* * *} P<0.0001$

† For details of diets and procedures see Tables 1 and 2 and pp. 300-301.

$\ddagger G, A, T, G \times T$ : mean significant effects of animal group $(G)$ tested against animals within group, of animal $(A)$, of tissue $(T)$ and of the group $\times$ tissue interaction $(G \times T)$. tissues. Thus, whatever the diet, CS activity was significantly higher in the heart than in the liver, RA and LT muscles (Table 5). In the same way, COX activity was significantly higher in the heart than in the liver, RA and LT muscles (Table 5). The mean COX:CS activity ratio differed also between tissues and was the highest in the liver (Table 5).

The activities of CS and COX were not affected by the diet. However, the mean COX: CS activity ratio was significantly lower in the liver of animals of the $\mathrm{CO}$ group than in that of the animals of the TA group $(15.2 v .25 .5$ respectively, $P<0 \cdot 01$; Table 5).

\section{Fatty acid oxidation rates in tissue homogenates}

Preliminary statistical analysis of all the data obtained in the four studied tissues, with three different substrates (laurate, palmitate and oleate) and with the two groups of calves revealed no significant effect of the diet on the tissue oxidation rates. However, great differences were present between tissues as previously described (Piot et al. 1998). Consequently, the data obtained with each tissue were then analysed and presented separately.

Liver. The oxidation rates of FA differed markedly with the type of FA used as a substrate $(P=0.006$; Table 6). Indeed, total oxidation rate was $2 \cdot 1$-fold higher with laurate than with oleate $(P<0.05)$ and peroxisomal oxidation rates as well as the contribution of peroxisomes to total FA oxidation were higher with laurate than with palmitate or oleate (3.8-fold and $2 \cdot 1$-fold, $P<0.05$ respectively; Table $6)$. When expressed per unit of mitochondrial enzyme activity, total oxidation rate was $2 \cdot 0$-fold higher with laurate than with oleate as substrate $(P<0.05$; Table 6$)$. Dietary lipids did not significantly affect the total or peroxisomal oxidative capacity of the liver whatever the expression of the results (Table 6).

Heart. The nature of the substrate used in the in vitro 
Table 5. Citrate synthase (EC 4.1.3.7) (CS) and cytochrome $c$ oxidase (EC 1.9.3.1) (COX) activities and mean COX: CS in different tissues from preruminant calves fed on either a milk-substitute rich in tallow (TA) or the same milk-substitute rich in coconut oil (CO) for 19 days $†$

(Values are means with their standard errors for five calves per group)

\begin{tabular}{|c|c|c|c|c|c|c|c|}
\hline & & \multicolumn{2}{|c|}{$\begin{array}{c}\text { CS activity } \\
\text { (U/g tissue wet wt.) }\end{array}$} & \multicolumn{2}{|c|}{$\begin{array}{c}\text { COX activity } \\
\text { (U/g tissue wet wt.) }\end{array}$} & \multicolumn{2}{|c|}{ COX:CS } \\
\hline & & TA diet & CO diet & TA diet & CO diet & TA diet & CO diet \\
\hline Liver & Mean & $3.45^{b}$ & $3.77^{b}$ & $83.0^{b}$ & $56 \cdot 1^{\mathrm{b}}$ & $25 \cdot 5^{\mathrm{a}}$ & $15 \cdot 2^{a * *}$ \\
\hline \multirow[t]{2}{*}{ Heart } & $\begin{array}{l}\text { SE } \\
\text { Mean }\end{array}$ & $\begin{array}{c}0.604 \\
28 \cdot 2^{\mathrm{a}}\end{array}$ & $\begin{array}{c}0.333 \\
39.0^{\mathrm{a}}\end{array}$ & $\begin{array}{r}8 \cdot 17 \\
231^{a}\end{array}$ & $\begin{array}{c}10 \cdot 28 \\
211^{a}\end{array}$ & $\begin{array}{l}2 \cdot 71 \\
9.64^{b}\end{array}$ & $\begin{array}{l}2.98 \\
6.28^{b}\end{array}$ \\
\hline & SE & $5 \cdot 138$ & 7.92 & 39.4 & 8.12 & 2.742 & 1.159 \\
\hline \multirow[t]{2}{*}{ RA } & Mean & $4 \cdot 71^{b}$ & $4.90^{b}$ & $24 \cdot 4^{b}$ & $25 \cdot 0^{\mathrm{b}}$ & $6.53^{b}$ & $5.29^{b}$ \\
\hline & & 0.984 & 0.688 & $6 \cdot 26$ & $2 \cdot 992$ & $2 \cdot 293$ & 0.593 \\
\hline \multirow[t]{2}{*}{ LT } & Mean & $4 \cdot 80^{\mathrm{b}}$ & $7 \cdot 38^{\mathrm{b}}$ & $19 \cdot 9^{b}$ & $23 \cdot 1^{\mathrm{b}}$ & $4 \cdot 46^{\mathrm{b}}$ & $3.42^{b}$ \\
\hline & SE & 0.612 & 1.166 & $6 \cdot 61$ & 3.416 & 1.428 & 0.605 \\
\hline \multicolumn{8}{|c|}{ Statistical significance of effect of: $P<\neq$} \\
\hline & \multicolumn{2}{|c|}{0.28} & \multicolumn{2}{|c|}{0.43} & \multicolumn{2}{|c|}{$0 \cdot 11$} \\
\hline \multicolumn{2}{|l|}{ A } & \multicolumn{2}{|c|}{0.10} & \multicolumn{2}{|c|}{0.16} & \multicolumn{2}{|c|}{0.002} \\
\hline \multicolumn{2}{|l|}{$\mathrm{T}$} & \multicolumn{2}{|c|}{0.0001} & \multicolumn{2}{|c|}{0.0001} & \multicolumn{2}{|c|}{0.0001} \\
\hline \multicolumn{2}{|l|}{$\mathrm{G} \times \mathrm{T}$} & \multicolumn{2}{|c|}{0.28} & \multicolumn{2}{|c|}{0.65} & \multicolumn{2}{|c|}{0.01} \\
\hline
\end{tabular}

RA, rectus abdominis; LT, longissimus thoracis.

${ }_{a, b}$ Mean values within a column with unlike superscript letters were significantly different within each group of calves $(P<0.05)$. Mean values were significantly different between the two groups for a given tissue: ${ }^{\star *} P<0.01$.

†For details of diets and procedures see Tables 1 and 2 and pp. 300-301.

$\ddagger \mathrm{G}, \mathrm{A}, \mathrm{T}$, and $\mathrm{G} \times \mathrm{T}$ : mean significant effects of animal group $(\mathrm{G})$ tested against animals within group, of animal $(A)$, and of tissue $(T)$ and of the group $\times$ tissue interaction $(G \times T)$.

assay mainly affected the activity of the peroxisomal system (Table 6). The highest peroxisomal oxidation rates and contribution of peroxisomes to total oxidation were observed when laurate was used as the substrate $(P<0.001$ and $P<$ $0 \cdot 01$ respectively).

In addition, the peroxisomal oxidation rate was also influenced by the FA composition of the milk-substitute $(P=0.04$; Table 6). Indeed, peroxisomal oxidation rate of oleate was $1 \cdot 5$-fold higher in the heart from calves fed on the $\mathrm{CO}$ diet than in those from calves fed on the TA diet $(P<0.05$; Table 6). Conversely, total oxidation rate did not vary with the diet or with the FA used in the assay whatever the expression of the results (i.e. perg wet tissue or per mitochondrial enzyme activity) (data not shown).

Rectus abdominis and longissimus thoracis skeletal muscles. As noted in the heart, peroxisomal oxidation rate of laurate in RA was 3.4-fold higher than those of oleate $(P<0.05$; Table 7$)$.

The FA composition of diets did not significantly influence the oxidative capacity of both muscles (Table 7). However, the contribution of the peroxisomes to the total oxidation rate of oleate was $2 \cdot 3$-fold higher in LT of calves fed on the $\mathrm{CO}$ diet than in calves fed on the TA diet $(P<$ 0.05; Table 7).

\section{Discussion}

\section{Animal characteristics and plasma variables}

Growth rates of calves were not affected by the nature of dietary FA as previously observed by Jenkins $e$ t al. (1985). These results do not confirm those of Aurousseau et al. $(1983,1984 a)$ who observed improved growth rate and $\mathrm{N}$ retention in preruminant calves when only one-third of the TA was replaced by $\mathrm{CO}$ for $2-4$ weeks. These discrepancies may reflect differences between experimental conditions, especially between the FA composition of the experimental diets. Feeding on the $\mathrm{CO}$ diet did not reduce food intake compared with those fed on the TA diet, in contrast to a milk-diet supplemented with soyabean oil (Leplaix-Charlat et al. 1996).

Previous analyses of blood samples of the same animals have shown that TG of chylomicrons in calves fed on the $\mathrm{CO}$ diet were rich in 12:0 (632 g/kg total FA) indicating that dietary laurate was preferentially transported by the lymphatic pathway rather than by the portal vein (Bauchart et al. 1998).

The lower plasma insulin level observed in calves of the $\mathrm{CO}$ group was unexpected since no change in rats and human subjects, and even an increased insulin concentration in rats fed on a diet containing medium-chain TG (6:0 and 8:0), have been described previously (for review, see Bach et al. 1996). Higher insulinaemia is generally attributed to a stimulation of insulin secretion by higher plasma levels of ketone bodies induced by the medium-chain TG diet. However, such a difference in plasma ketone bodies concentration was not observed in our study, probably because the $\mathrm{CO}$ diet was supplied with carbohydrate in sufficient amounts to suppress ketogenesis (for review, see Bach et al. 1996). Alternatively, the low plasma insulinaemia in the $\mathrm{CO}$ group may be explained by a lower stimulation of the glucoseinduced secretion of insulin by medium-chain FA than by long-chain FA (Stein et al. 1997). In addition, the lower plasma insulin and glucose levels in the $\mathrm{CO}$ group may indicate an increased insulin sensitivity of peripheral tissues such as muscles (Bauchart et al. 1996) as observed in human subjects during eucaloric medium-chain TG substitution (Wilson et al. 1983; Eckel et al. 1992). Furthermore, a low insulinaemia in calves fed on the $\mathrm{CO}$ diet can reduce the 
Table 6. Oxidation rates of fatty acids in liver and heart homogenates from preruminant calves fed on either a milk-substitute rich in tallow (TA) or the same milk-substitute rich in coconut oil (CO) for 19 days $\dagger$

(Values are means with their standard errors for five calves per group)

\begin{tabular}{|c|c|c|c|c|c|c|c|c|c|c|c|c|c|c|}
\hline \multirow[b]{3}{*}{ Fatty acid . } & & \multicolumn{9}{|c|}{ Fatty acid oxidation rate } & \multirow{2}{*}{\multicolumn{4}{|c|}{$\begin{array}{l}\text { Statistical significance of } \\
\text { effect of: } P<\neq\end{array}$}} \\
\hline & & \multicolumn{3}{|c|}{ TA diet } & \multicolumn{3}{|c|}{ CO diet } & \multicolumn{3}{|c|}{ Average } & & & & \\
\hline & & 12:0 & 16:0 & $18: 1$ & $12: 0$ & 16:0 & $18: 1$ & $12: 0$ & 16:0 & $18: 1$ & $\mathrm{G}$ & A & FA & $\mathrm{G} \times \mathrm{FA}$ \\
\hline \multicolumn{15}{|l|}{ Liver } \\
\hline $\begin{array}{l}\text { Total oxidation rate } \\
\text { (nmol/min per } \mathrm{g} \text { tissue wet wt.) }\end{array}$ & $\begin{array}{l}\text { Mean } \\
\text { SE }\end{array}$ & $\begin{array}{r}432^{\mathrm{a}} \\
80 \cdot 4\end{array}$ & $\begin{array}{r}284^{\mathrm{a}} \\
64 \cdot 4\end{array}$ & $\begin{array}{r}218^{\mathrm{a}} \\
23 \cdot 0\end{array}$ & $\begin{array}{l}363^{\mathrm{a}} \\
101 \cdot 8\end{array}$ & $\begin{array}{l}268^{a} \\
20 \cdot 4\end{array}$ & $\begin{array}{c}163^{\mathrm{a}} \\
19 \cdot 4\end{array}$ & $\begin{array}{r}397^{\mathrm{a}} \\
62 \cdot 2\end{array}$ & $\begin{array}{r}276^{\mathrm{ab}} \\
32 \cdot 0\end{array}$ & $\begin{array}{r}187^{\mathrm{b}} \\
27 \cdot 9\end{array}$ & 0.63 & $0 \cdot 15$ & 0.006 & 0.86 \\
\hline Peroxisomal oxidation rate & Mean & $169^{a}$ & $65 \cdot 4^{\mathrm{b}}$ & $33 \cdot 2^{b}$ & $189^{a}$ & $63.0^{\mathrm{b}}$ & $39 \cdot 8^{\mathrm{b}}$ & $179^{a}$ & $64 \cdot 2^{\mathrm{b}}$ & $36 \cdot 9^{\mathrm{b}}$ & 0.45 & 0.57 & 0.0001 & 0.80 \\
\hline (nmol/min per g tissue wet wt.) & SE & $29 \cdot 0$ & 8.55 & $2 \cdot 34$ & $26 \cdot 4$ & 3.93 & 1.76 & $18 \cdot 8$ & 4.46 & 2.74 & & & & \\
\hline Contribution of peroxisomal to total oxidation (\%)§ & Mean & $\begin{array}{c}42 \cdot 0^{\mathrm{ab}} \\
5.86\end{array}$ & $\begin{array}{c}28.6^{\mathrm{ab}} \\
7 \cdot 30\end{array}$ & $\begin{array}{c}18 \cdot 8^{\mathrm{ab}} \\
3.81\end{array}$ & $\begin{array}{l}67.9^{\mathrm{a}} \\
16 \cdot 58\end{array}$ & $\begin{array}{r}24 \cdot 0^{\mathrm{b}} \\
2 \cdot 30\end{array}$ & $\begin{array}{c}32 \cdot 1^{\mathrm{ab}} \\
5 \cdot 36\end{array}$ & $\begin{array}{r}55 \cdot 0^{\mathrm{a}} \\
9 \cdot 34\end{array}$ & $\begin{array}{r}26 \cdot 3^{\mathrm{b}} \\
3.67\end{array}$ & $\begin{array}{r}26 \cdot 2^{b} \\
6 \cdot 68\end{array}$ & $0 \cdot 30$ & $0 \cdot 13$ & 0.005 & 0.21 \\
\hline Total oxidation per unit of citrate synthase & Mean & $129^{a}$ & $98 \cdot 7^{\mathrm{a}}$ & $67 \cdot 3^{\mathrm{a}}$ & $103^{\mathrm{a}}$ & $72 \cdot 8^{\mathrm{a}}$ & $45 \cdot 5^{\mathrm{a}}$ & $116^{\mathrm{a}}$ & $85 \cdot 7^{\mathrm{ab}}$ & $55 \cdot 2^{b}$ & 0.43 & 0.01 & 0.006 & 0.90 \\
\hline$(E C$ 4.1.3.7) $(\mathrm{nmol} / \mathrm{min}$ per $\mathrm{U})$ & SE & 21.9 & 29.7 & $9 \cdot 26$ & 36.6 & 6.68 & 6.68 & 19.0 & $15 \cdot 00$ & $10 \cdot 35$ & & & & \\
\hline $\begin{array}{l}\text { Total oxidation per unit of cytochrome } c \text { oxidase } \\
\quad(E C \text { 1.9.3.1) }(\mathrm{nmol} / \mathrm{min} \text { per } U)\end{array}$ & $\begin{array}{l}\text { Mean } \\
\text { SE }\end{array}$ & $\begin{array}{l}5.01^{\mathrm{a}} \\
0.644\end{array}$ & $\begin{array}{l}3.56^{\mathrm{a}} \\
0.796\end{array}$ & $\begin{array}{l}2 \cdot 48^{\mathrm{a}} \\
0.280\end{array}$ & $\begin{array}{l}8 \cdot 14^{\mathrm{a}} \\
4 \cdot 235\end{array}$ & $\begin{array}{l}5 \cdot 47^{\mathrm{a}} \\
1.020\end{array}$ & $\begin{array}{l}3.87^{\mathrm{a}} \\
0.893\end{array}$ & $\begin{array}{l}6.58^{\mathrm{a}} \\
1.885\end{array}$ & $\begin{array}{l}4.51^{\mathrm{ab}} \\
0.688\end{array}$ & $\begin{array}{l}3.26^{b} \\
0.992\end{array}$ & 0.35 & 0.005 & 0.04 & 0.82 \\
\hline \multicolumn{15}{|l|}{ Heart } \\
\hline $\begin{array}{l}\text { Total oxidation rate } \\
\text { (nmol/min per } \mathrm{g} \text { tissue wet wt.) }\end{array}$ & $\begin{array}{l}\text { Mean } \\
\text { SE }\end{array}$ & $\begin{array}{r}187^{\mathrm{a}} \\
21.0\end{array}$ & $\begin{array}{r}167^{\mathrm{a}} \\
16 \cdot 5\end{array}$ & $\begin{array}{r}147^{\mathrm{a}} \\
20 \cdot 9\end{array}$ & $\begin{array}{r}204^{\mathrm{a}} \\
45 \cdot 3\end{array}$ & $\begin{aligned} & 190^{\mathrm{a}} \\
& 7.92\end{aligned}$ & $\begin{array}{c}170^{\mathrm{a}} \\
20 \cdot 8\end{array}$ & $\begin{array}{r}194^{\mathrm{a}} \\
21 \cdot 8\end{array}$ & $\begin{array}{l}178^{\mathrm{a}} \\
9 \cdot 39\end{array}$ & $\begin{array}{c}159^{\mathrm{a}} \\
14 \cdot 41\end{array}$ & 0.46 & 0.07 & $0 \cdot 26$ & 0.92 \\
\hline $\begin{array}{l}\text { Peroxisomal oxidation rate } \\
\quad \text { (nmol per g tissue wet wt.) }\end{array}$ & Mean & $\begin{array}{c}46 \cdot 5^{\mathrm{ab}} \\
7.00\end{array}$ & $\begin{array}{c}35 \cdot 2^{\mathrm{ab}} \\
3.41\end{array}$ & $\begin{array}{r}22 \cdot 4^{b} \\
1.18\end{array}$ & $\begin{array}{r}57.2^{\mathrm{a}} \\
4.43\end{array}$ & $\begin{array}{c}44.8^{\mathrm{ab}} \\
8.50\end{array}$ & $\begin{array}{c}33 \cdot 1^{b *} \\
3 \cdot 40\end{array}$ & $\begin{array}{r}54.1^{\mathrm{a}} \\
4.95\end{array}$ & $\begin{array}{r}40.0^{\mathrm{b}} \\
4.60\end{array}$ & $\begin{array}{r}27 \cdot 8^{\mathrm{b}} \\
2.47\end{array}$ & 0.04 & 0.22 & 0.0004 & 0.81 \\
\hline Contribution of peroxisomal to total oxidation (\%)§ & $\begin{array}{l}\text { Mean } \\
\text { SE }\end{array}$ & $\begin{array}{c}24.9^{\mathrm{ab}} \\
2.58\end{array}$ & $\begin{array}{c}21 \cdot 8^{\mathrm{ab}} \\
3 \cdot 10\end{array}$ & $\begin{array}{r}16 \cdot 2^{b} \\
2 \cdot 01\end{array}$ & $\begin{array}{l}35 \cdot 8^{\mathrm{a}} \\
11 \cdot 76\end{array}$ & $\begin{array}{c}23.9^{\mathrm{ab}} \\
4.97\end{array}$ & $\begin{array}{r}20 \cdot 7^{\mathrm{ab}} \\
3 \cdot 691\end{array}$ & $\begin{array}{r}29.7^{\mathrm{a}} \\
5.35\end{array}$ & $\begin{array}{c}22 \cdot 8^{\mathrm{ab}} \\
2 \cdot 78\end{array}$ & $\begin{array}{r}18 \cdot 4^{b} \\
2 \cdot 12\end{array}$ & 0.23 & 0.03 & 0.01 & 0.25 \\
\hline
\end{tabular}

${ }_{\mathrm{a}, \mathrm{b}}$ Mean values within a row with unlike superscript letters were significantly different $(P<0.05)$.

Mean values were significantly different between the two groups: ${ }^{*} P<0.05$.

$\dagger$ For details of diets and procedures see Tables 1 and 2 and pp. $300-301$

$\neq G, A, F A$ and $G \times F A$ : mean significant effects of animal group $(G)$ tested against animals within a group, of animal $(A)$, of fatty acid (FA) and of group $\times$ fatty acid interaction $(G \times F A)$

$\S$ Contribution of peroxisomal oxidation represents the proportion of peroxisomal to total oxidation rate. 
Table 7. Oxidation rates of fatty acids in skeletal muscle homogenates from preruminant calves fed on either a milk-substitute rich in tallow (TA) or the same milk-substitute rich in coconut oil (CO) for 19 days $\dagger$

(Values are means with their standard errors for five calves per group)

\begin{tabular}{|c|c|c|c|c|c|c|c|c|c|c|c|c|c|c|}
\hline \multirow[b]{3}{*}{ Fatty acid ... } & & \multicolumn{9}{|c|}{ Fatty acid oxidation rate } & \multirow{2}{*}{\multicolumn{4}{|c|}{$\begin{array}{l}\text { Statistical significance of } \\
\text { effect of: } P<\neq\end{array}$}} \\
\hline & & \multicolumn{3}{|c|}{ TA diet } & \multicolumn{3}{|c|}{ CO diet } & \multicolumn{3}{|c|}{ Average } & & & & \\
\hline & & $12: 0$ & $16: 0$ & $18: 1$ & $12: 0$ & 16:0 & $18: 1$ & $12: 0$ & 16:0 & $18: 1$ & $\mathrm{G}$ & $A$ & $\mathrm{FA}$ & $G \times F A$ \\
\hline \multicolumn{15}{|l|}{ Rectus abdominis } \\
\hline $\begin{array}{l}\text { Total oxidation rate } \\
\text { (nmol/min per g tissue wet wt.) }\end{array}$ & $\begin{array}{l}\text { Mean } \\
\text { SE }\end{array}$ & $\begin{array}{r}28.0^{\mathrm{a}} \\
8.80\end{array}$ & $\begin{array}{r}30 \cdot 7^{\mathrm{a}} \\
5 \cdot 00\end{array}$ & $\begin{array}{r}20 \cdot 9^{\mathrm{a}} \\
3.91\end{array}$ & $\begin{array}{r}27 \cdot 2^{\mathrm{a}} \\
3.80\end{array}$ & $\begin{array}{r}19 \cdot 0^{\mathrm{a}} \\
3 \cdot 35\end{array}$ & $\begin{array}{r}15 \cdot 0^{\mathrm{a}} \\
3.95\end{array}$ & $\begin{array}{r}27.6^{\mathrm{a}} \\
4.76\end{array}$ & $\begin{array}{r}24.8^{\mathrm{a}} \\
3.44\end{array}$ & $\begin{array}{r}17 \cdot 9^{\mathrm{a}} \\
2 \cdot 80\end{array}$ & 0.23 & 0.22 & $0 \cdot 14$ & 0.53 \\
\hline Peroxisomal oxidation rate & Mean & $16 \cdot 8^{\mathrm{a}}$ & $8.60^{\mathrm{b}}$ & $3.80^{\mathrm{a}}$ & $12 \cdot 5^{\mathrm{a}}$ & $6.60^{\mathrm{a}}$ & $4.60^{\mathrm{a}}$ & $14 \cdot 4^{\mathrm{a}}$ & $7.60^{\mathrm{ab}}$ & $4 \cdot 21^{\mathrm{b}}$ & 0.60 & 0.25 & 0.01 & 0.75 \\
\hline (nmol/min per g tissue wet wt.) & SE & 7.01 & 2.81 & 0.323 & 2.63 & 2.76 & 1.044 & 3.27 & 1.88 & 0.53 & & & & \\
\hline Contribution of peroxisomal to total oxidation (\%)§ & $\begin{array}{l}\text { Mean } \\
\text { SE }\end{array}$ & $\begin{array}{r}48 \cdot 6^{\mathrm{a}} \\
8.90\end{array}$ & $\begin{array}{r}27 \cdot 7^{\mathrm{a}} \\
6 \cdot 04\end{array}$ & $\begin{array}{r}23 \cdot 9^{\mathrm{a}} \\
8.45\end{array}$ & $\begin{array}{r}47 \cdot 2^{\mathrm{a}} \\
8.34\end{array}$ & $\begin{array}{r}34 \cdot 1^{a} \\
9 \cdot 24\end{array}$ & $\begin{array}{l}40 \cdot 7^{\mathrm{a}} \\
12 \cdot 23\end{array}$ & $\begin{array}{r}47 \cdot 8^{a} \\
5 \cdot 71\end{array}$ & $\begin{array}{r}30 \cdot 9^{a} \\
5 \cdot 31\end{array}$ & $\begin{array}{r}32 \cdot 3^{\mathrm{a}} \\
7.55\end{array}$ & 0.46 & 0.08 & 0.04 & 0.50 \\
\hline \multicolumn{15}{|l|}{ Longissimus thoracis } \\
\hline $\begin{array}{l}\text { Total oxidation rate } \\
\text { (nmol/min per g tissue wet wt.) }\end{array}$ & $\begin{array}{l}\text { Mean } \\
\text { SE }\end{array}$ & $\begin{array}{r}26 \cdot 3^{\mathrm{a}} \\
5 \cdot 38\end{array}$ & $\begin{array}{r}24 \cdot 2^{\mathrm{a}} \\
3.39\end{array}$ & $\begin{array}{r}18 \cdot 8^{\mathrm{a}} \\
4.79\end{array}$ & $\begin{array}{r}20 \cdot 9^{a} \\
3 \cdot 81\end{array}$ & $\begin{array}{r}25 \cdot 0^{\mathrm{a}} \\
5 \cdot 62\end{array}$ & $\begin{array}{r}14 \cdot 7^{\mathrm{a}} \\
4 \cdot 00\end{array}$ & $\begin{array}{r}23 \cdot 3^{\mathrm{a}} \\
3 \cdot 12\end{array}$ & $\begin{array}{r}24 \cdot 6^{\mathrm{a}} \\
1 \cdot 12\end{array}$ & $\begin{array}{r}16 \cdot 8^{\mathrm{a}} \\
3 \cdot 01\end{array}$ & 0.66 & 0.007 & 0.05 & 0.67 \\
\hline $\begin{array}{l}\text { Peroxisomal oxidation rate } \\
\text { (nmol/min per q tissue wet wt.) }\end{array}$ & $\begin{array}{l}\text { Mean } \\
\text { SE }\end{array}$ & $\begin{array}{l}8 \cdot 64^{\mathrm{a}} \\
4.43\end{array}$ & $\begin{array}{l}6 \cdot 16^{\mathrm{a}} \\
1.24\end{array}$ & $\begin{array}{l}3.04^{a} \\
0.559\end{array}$ & $\begin{array}{l}5 \cdot 95^{\mathrm{a}} \\
2.98\end{array}$ & $\begin{array}{l}7.39^{\mathrm{a}} \\
1.975\end{array}$ & $\begin{array}{l}3 \cdot 66^{\mathrm{a}} \\
0.852\end{array}$ & $\begin{array}{l}7 \cdot 15^{\mathrm{a}} \\
2 \cdot 44\end{array}$ & $\begin{array}{l}6 \cdot 77^{\mathrm{a}} \\
1 \cdot 12\end{array}$ & $\begin{array}{l}3 \cdot 35^{\mathrm{a}} \\
0.491\end{array}$ & 0.96 & 0.08 & $0 \cdot 12$ & 0.65 \\
\hline Contribution of peroxisomal to total oxidation (\%)§ & $\begin{array}{l}\text { Mean } \\
\text { SE }\end{array}$ & $\begin{array}{l}32 \cdot 9^{\mathrm{a}} \\
12 \cdot 22\end{array}$ & $\begin{array}{r}26 \cdot 8^{\mathrm{a}} \\
5 \cdot 76\end{array}$ & $\begin{array}{r}12 \cdot 7^{\mathrm{a}} \\
1.94\end{array}$ & $\begin{array}{r}22.9^{\mathrm{a}} \\
9.77\end{array}$ & $\begin{array}{l}31.3^{\mathrm{a}} \\
6.69\end{array}$ & $\begin{array}{c}29.7^{\mathrm{a} *} \\
5.85\end{array}$ & $\begin{array}{r}27 \cdot 3^{\mathrm{a}} \\
7 \cdot 38\end{array}$ & $\begin{array}{r}29 \cdot 1^{\mathrm{a}} \\
4.23\end{array}$ & $\begin{array}{r}21 \cdot 1^{\mathrm{a}} \\
4 \cdot 37\end{array}$ & 0.66 & 0.26 & 0.67 & 0.34 \\
\hline
\end{tabular}

a,b Mean values within a row with unlike superscript letters were significantly different $(P<0.05)$.

Mean values were significantly different between the two groups: * $P<0.05$.

$\ddagger G, A, F A$ and $G \times F A$ : mean significant effects of animal group $(G)$ tested against animals within a group, of animal (A), of fatty acid (FA) and of group $\times$ fatty acid interaction (G $\times F A)$.

\$Contribution of peroxisomal oxidation represents the proportion of peroxisomal to total oxidation rate. 
intracellular degradation of the apolipoprotein B which is considered as one of the rate-limiting steps for the hepatic secretion of TG-VLDL (Gruffat et al. 1996). In these conditions, the liver of calves fed on the $\mathrm{CO}$ diet may produce a higher quantity of VLDL. However, the rate of hepatic production of VLDL is probably not high enough to avoid storage of TG since TG accumulated in the liver of calves fed on the $\mathrm{CO}$ diet.

\section{Hepatic fatty acid oxidation}

The higher hepatic oxidation rate of laurate than of oleate was in accordance with previous results obtained in rats (Leighton et al. 1984; Christensen et al. 1989). Similarly, the higher hepatic TG content with the CO diet confirms previous data in gerbils (Nicolisi et al. 1976) and rats (Bouziane et al. 1997). The question is thus to understand how a laurate-rich diet can lead to a higher hepatic TG content while laurate is better oxidized than long-chain FA by liver.

Generally, medium-chain FA can be oxidized by $\beta$ oxidation in liver cells by three different mechanisms; (1) carnitine-dependent mitochondrial $\beta$-oxidation, (2) carnitineindependent mitochondrial oxidation and (3) peroxisomal $\beta$-oxidation (for review, see Hocquette \& Bauchart, 1999). The high rate of oxidation of laurate in liver homogenates may be explained in part by its high peroxisomal $\beta$-oxidation as observed in our study but also by a high carnitineindependent mitochondrial $\beta$-oxidation as observed in isolated rat hepatocytes (Christensen et al. 1989). The high peroxisomal oxidation rate of laurate may represent a metabolic adaptation of hepatocytes in response to an excessive uptake of FA by the liver (Christiansen et al. 1985). The latter may be due, at least in part, to the higher digestibility and hence, metabolizable energy value of a milk-substitute rich in $\mathrm{CO}$ compared with that rich in TA (Table 1; Aurousseau et al. 1984b). Alternatively, partly oxidized laurate may be secreted by the liver as ketone bodies. However, plasma levels of ketone bodies did not differ between the two groups of calves.

The hepatic accumulation of TG in calves fed on the $\mathrm{CO}$ diet can result from; (1) a higher rate of direct esterification of FA, especially of laurate, (2) a higher rate of hepatic de novo lipogenesis or of FA elongation, and/or (3) a lower rate of VLDL secretion. The first mechanism is unlikely since the esterification rate is known to be lower for laurate than for oleate in rats (Christensen et al. 1989). Similarly to the calves in the present study, laurate is weakly incorporated into hepatic TG compared with myristate and palmitate (10.4, 38.1 and $29.0 \%$ of FA in total hepatic TG respectively; Bauchart et al. 1998). The second mechanism is more likely since dietary medium-chain TG (6:0 and 8:0) can promote substantial synthesis of long-chain FA (18:0 and 16:0) by the liver (Crozier, 1988). Our results, i.e. the high peroxisomal oxidation rate of laurate, suggest that after an initial peroxisomal $\beta$-oxidation to shorter FA, acyl-CoA or acetyl-CoA followed by de novo synthesis or utilization for chain elongation, the lauric acid can be retailored into long-chain FA, and finally incorporated in TG, as previously described for laurate in the rat liver (Christensen et al. 1989). In this context, the hepatic TG accumulation may be amplified by the 8-fold lower ability of the ruminant liver to secrete TG-VLDL compared with the rat (for review, see Gruffat et al. 1996; Hocquette \& Bauchart, 1999) since lipogenesis rate is higher with a medium-chain FA-rich diet (6:0 and 8:0) than with dietary long-chain TG in the rat (Takase \& Hosoya 1986; Crozier, 1988). This mechanism is likely to operate in the calf despite a low lipogenic capacity of the bovine liver. Indeed, the rate of de novo FA synthesis is at least 50-fold lower in the bovine liver than in the rat liver (for review, see Hocquette \& Bauchart, 1999) whereas the difference in FA elongation rate between the two species is much smaller, i.e. approximately 3-fold (St John et al. 1991). This is explained, at least in part, by the very low activity of acetyl-CoA synthetase (EC 6.2.1.1) in the bovine liver (Ricks \& Cook, 1981). This enzyme is not involved in the process of FA elongation from acetyl-CoA, but is involved in the process of FA synthesis from acetate.

\section{Cardiac and muscular fatty acid oxidation}

In these tissues, the nature of FA used as substrate and the type of dietary fat incorporated into the milk-substitute mainly regulate the rate of peroxisomal FA $\beta$-oxidation. Thus, in the heart, the shorter the chain length of FA, the more important is the contribution of peroxisomes to total FA oxidation $(12: 0>18: 1)$. As previously described in rat heart (Reubsaet et al. 1989), no difference has been detected between 16:0 and 18:1. The similar mitochondrial and peroxisomal FA oxidation rates in both RA and LT of the two groups of calves indicate the lack of effect of dietary FA on the oxidative capacity of these two muscles. These muscles are indeed glycolytic (LT) or oxido-glycolytic (RA) tissues in contrast to the heart (oxidative tissue). This confirms the results of Power \& Newsholme (1997) who demonstrated in rats that dietary FA, and especially $\mathrm{CO}$ have less influence on the activity and the regulation of carnitine palmitoyltransferase I (EC 2.3.1.21) in heart and muscles than in liver. In addition, this latter study showed that dietary FA required a feeding period longer than 4 weeks to affect FA oxidation of the muscles.

In conclusion, simultaneous determination of FA oxidation in liver, in heart and in skeletal muscles provided us with more insight of the metabolic fate of dietary FA from $\mathrm{CO}$ diet. The higher growth rate and $\mathrm{N}$ retention in calves fed on a milk-diet containing a mixture of $\mathrm{CO}$ and TA suggested a higher production of energy in muscles favouring protein deposition in this tissue (Aurousseau et al. 1984a). Our study showed, by in vitro approach, that FA oxidation capacity was similar in the heart and skeletal muscles with the TA and $\mathrm{CO}$ milks but in vivo FA oxidation remains to be studied with these two diets. A higher oxidation rate of laurate was observed in hepatic peroxisomes which may induce TG accumulation after short-chain FA elongation. The fatty liver induced by $\mathrm{CO}$ diet can affect, in the longterm, the health of calves (for review, see Hocquette \& Bauchart, 1999). Furthermore, the simultaneous induction of the oxidative and lipogenesis pathways by medium-chain FA in the liver is energetically costly (Hill et al. 1990) and could compete with other energetic processes such as protein synthesis in muscle tissues during the intense growth of preruminant calves. This hypothesis needs to be confirmed in vivo. 


\section{Acknowledgements}

The authors are grateful to M. Martinaud-Brunel, C. Legay and N. Guivier for skilful technical assistance, to M. Tourret and $\mathrm{Y}$. Chilliard for assay of $\beta$-hydroxybutyrate plasma levels and to C. Leoty and R. Souchet (INRA, Unité de Recherches sur les Herbivores) for the excellent maintenance and care of the animals.

\section{References}

Aurousseau B, Thivend P \& Vermorel M (1984a) Influence du remplacement d'une partie du suif d'un aliment par de la tricaproïne ou de la tricapryline en association à de l'huile de coprah sur la croissance du jeune veau préruminant (Influence of substituting part of the milk replacer tallow by tricaproin or tricaprylin combined with coconut oil on the growth of young preruminant calves). Annales de Zootechniues 33, 219-234.

Aurousseau B, Vermorel M \& Bouvier JC (1983) Influence du remplacement d'une partie du suif d'un aliment d'allaitement par de la tricaproïne ou de l'huile de coprah, sur l'utilisation de l'énergie et de l'azote par le veau préruminant; influence du niveau d'alimentation antérieur (Effect on energy and nitrogen balances of replacing part of the tallow in a milk replacer for preruminant calves by tricaproin or coconut oil: effect of previous feeding level). Reproduction Nutrition Développement 23, 587-597.

Aurousseau B, Vermorel M \& Bouvier JC (1984b) Influence du remplacement d'une partie du suif d'un aliment d'allaitement par de la tricapryline ou de l'huile de coprah sur l'utilisation de l'énergie et de l'azote par le veau préruminant (Effect on energy and nitrogen balances of substituting tricaprylin or coconut oil for a part of the tallow in a milk replacer for the preruminant calf). Reproduction Nutrition Développement 24, 265-279.

Bach AC, Ingenbleek Y \& Frey A (1996) The usefulness of dietary medium-chain triglycerides in body weight control: fact or fancy? Journal of Lipid Research 37, 708-726.

Barnouin J, El Idilbi N, Chilliard Y, Chacornac JP \& Lefaivre R (1986) Automated micro-determination of bovine plasma 3-hydroxybutyrate without deproteinization. Annales de Recherches Vétérinaires 17, 129-139.

Bauchart D, Durand D, Picherit C, Graulet B \& Gruffat D (1998) Effects of dietary coconut oil on blood transport and in vivo hepatic metabolism of fatty acids in the preruminant calf. Reproduction Nutrition Development 38, 203.

Bauchart D, Ortigues I, Hocquette JF, Guffant D \& Durand D (1996) Energy and fat metabolism of the liver, the digestive tract and muscles: transporting, processing, energy consumption and fixation by tissues. In Veal, Perspectives to the Year 2000, Proceedings of the International Symposium, Le Mans, France, pp. 255-290 [The French Federation of Veal Producers, editors]. Le Mans, France: Presse de Jouve.

Bouziane M, Belleville J \& Prost J (1997) Hepatic storage and transport of $n-3$ and $n-6$ polyunsaturated fatty acids by very-low density lipoproteins in growing rats fed low- or adequate-protein diets with sunflower, soybean, coconut, and salmon oils. American Journal of Clinical Nutrition 65, 750-760.

Christensen E, Hagve TA, Gronn M \& Christopherson BO (1989) $\beta$-Oxidation of medium chain $\left(\mathrm{C}_{8}-\mathrm{C}_{14}\right)$ fatty acids studied in isolated liver cells. Biochimica et Biophysica Acta 1004, 187195.

Christiansen EN, Gray TJ \& Lake BG (1985) Effect of very-long chain fatty acids on peroxisomal beta-oxidation in primary rat hepatocyte cultures. Lipids 20, 929-932.

Craig SR \& Gatlin DM (1995) Coconut oil and beef tallow, but not tricaprylin, can replace menhaden oil in the diet of red drum
(Sciaenops ocellatus) without adversely affecting growth or fatty acid composition. Journal of Nutrition 125, 3041-3048.

Crozier GL (1988) Medium-chain triglycerides feeding over the long term: the metabolic fate of $\left[{ }^{14} \mathrm{C}\right]$ octanoate and $\left[{ }^{14} \mathrm{C}\right]$ oleate in isolated rat hepatocytes. Journal of Nutrition 118, 297304.

Demarne Y, Epo N, Flanzy J \& Lecourtier MJ (1978) Comparison of long-term lipogenic effects of two different medium-chain triglycerides (tri $\mathrm{C}_{8}: 0$ and tri $\mathrm{C}_{12}: 0$ ) in the growing rat. Archives Internationales de Physiologie et de Biochimie 86, 25-35.

Durand D \& Bauchart D (1986) Variations nyctémérales de la lipémie et de la glycémie au niveau des voies afférentes et efférentes du foie chez le veau préruminant (Nyctemeral variations of lipaemia and glycaemia in afferent and efferent hepatic blood vessels in the preruminant calf). Reproduction Nutrition Développement 26, 371-372.

Eckel RH, Hanson AS, Chen AY, Berman JN, Yost TJ \& Brass EP (1992) Dietary substitution of medium-chain triglycerides improves insulin-mediated glucose metabolism in NIDDM subjects. Diabetes 41, 641-647.

Folch J, Lees M \& Sloane-Stanley GHS (1957) A simple method of the isolation and purification of total lipides from animal tissues. Journal of Biological Chemistry 226, 497-509.

Gruffat D, Durand D, Graulet B \& Bauchart D (1996) Regulation of VLDL synthesis and secretion in the liver. Reproduction Nutrition Development 36, 375-389.

Hill JO, Peters JC, Swift L, Yang D, Sharp T, Abumrad N \& Greene H (1990) Changes in blood lipids during six days of overfeeding with medium or long-chain triglycerides. Journal of Lipid Research 31, 407-416.

Hocquette JF \& Bauchart D (1999) Intestinal absorption, blood transport and hepatic and muscle metabolism of fatty acids in preruminant and ruminant animals. Reproduction Nutrition Development 39, 27-48.

Hocquette JF, Bornes F, Balage M, Ferre P, Grizard J \& Vermorel M (1995) Glucose-transporter (GLUT4) protein content in oxidative and glycolytic skeletal muscles from calf and goat. Biochemical Journal 305, 465-470.

Hocquette JF, Ortigues-Marty I \& Vermorel M (1998) Nutritional regulation of energy metabolism in growing ruminants. In Proceedings of the Symposium on Growth in Ruminants: Basic Aspects, Theory and Practice for the Future, pp. 76-85 [JW Blum, T Elsasser and P Guilloteau, editors]. Berne, Switzerland: University of Berne.

Jenkins KJ, Kramer JKG, Sauer FD \& Emmons DB (1985) Influence of triglycerides and free fatty acids in milk replacers on calf performance, blood plasma, and adipose lipids. Journal of Dairy Science 68, 669-680.

Leighton F, Pérrico R \& Necochea C (1984) Peroxisomal fatty acid oxidation is selectively inhibited by phenothiazines in isolated hepatocytes. Biochemical and Biophysical Research Communications 120, 505-511.

Leplaix-Charlat L, Durand D \& Bauchart D (1996) Effects of diets containing tallow and soybean oil with and without cholesterol on hepatic metabolism of lipids and lipoproteins in the preruminant calf. Journal of Dairy Science 79, 1826-1835.

Leyton J, Drury PJ \& Crawford MA (1987) Differential oxidation of saturated and unsaturated fatty acids in vivo in the rat. British Journal of Nutrition 57, 383-393.

Miller GM, Conrad JH, Keenan TW \& Featherston WR (1971) Fatty acid oxidation in young pigs. Journal of Nutrition 101, 1343-1350.

Nicolisi R, Herrera MG, El Hozy M \& Hayes KC (1976) Effect of dietary fat on hepatic metabolism of ${ }^{14} \mathrm{C}$-oleic acid and very-low density lipoprotein triglycerides in the gerbil. Journal of Nutrition 106, 1279-1285.

Piot C, Veerkamp JH, Durand D, Bauchart D \& Hocquette JF 
(1998) Contribution of mitochondria and peroxisomes to palmitate oxidation in rat and bovine tissues. Comparative Biochemistry and Physiology 121B, 69-78.

Power GW \& Newsholme EA (1997) Dietary fatty acids influence the activity and metabolic control of mitochondrial carnitine palmitoyltransferase I in rat heart and skeletal muscle. Journal of Nutrition 127, 2142-2150.

Reubsaet FAG, Veerkamp JH, Trijbels JMF \& Monnens LAH (1989) Total and peroxisomal oxidation of various saturated and unsaturated fatty acids in the rat liver, heart and M. quadriceps. Lipids 24, 945-950.

Ricks CA \& Cook RM (1981) Regulation of volatile fatty acid uptake by mitochondrial acyl-CoA synthetases of bovine liver. Journal of Dairy Science 64, 2324-2335.

Stein DT, Stevenson BE, Chester MW, Basit M, Daniels MB, Turley SD \& McGarry JD (1997) The insulinotropic potency of fatty acids is influenced profoundly by their chain length and degree of saturation. Journal of Clinical Investigation 100, 398-403.

St John LC, Lunt DK \& Smith SB (1991) Fatty acid elongation and desaturation enzyme activities of bovine liver and subcutaneous adipose tissue microsomes. Journal of Animal Science 69, 1064-1073.

Takase S \& Hosoya N (1986) Effect of dietary medium-chain triglycerides on lipogenic enzyme activity in rat liver. Journal of Nutrition Science and Vitaminology 32, 219-227.

Toullec R (1978) Le Veau (The Calf). In INRA Alimentation des Ruminants, pp. 270-271. Versailles, France: INRA Publications.

Veerkamp JH \& Van Moerkerk HTB (1986) Peroxisomal fatty acid oxidation in rat and human tissues. Effect of nutritional state, clofibrate treatment and postnatal development in the rat. Biochimica et Biophysica Acta 875, 301-310.

Wiley JH \& Leveille GA (1973) Metabolic consequences of dietary medium-chain triglycerides in the rat. Journal of Nutrition 103, 829-835.

Wilson DE, Chan IF, Stevenson KB, Horton SC \& Schipke C (1983) Eucaloric substitution of medium-chain triglycerides for dietary long chain fatty acids in acquired total lipodystrophy: effects on hyperlipoproteinemia and endogenous insulin resistance. Journal of Clinical Endocrinology and Metabolism 57, 517-523.

Yaqoob P, Sherrington EJ, Jeffery NM, Sanderson P, Harvey DJ, Newsholme C \& Calder PC (1995) Comparison of the effects of a range of dietary lipids upon serum and tissue lipid composition in the rat. International Journal of Biochemistry and Cellular Biology 27, 297-310. 